\title{
Comparison of four methods of inducing pseudopregnancy in rabbits
}

\author{
(1) SYAFRUDDIN SYAFRUDDIN ${ }^{1,2}$, OSRI WAHYUNI ${ }^{3}$, \\ (1) GHOLIB GHOLIB ${ }^{4}$, (1)TONGKU NIZWAN SIREGAR ${ }^{5}$
}

\begin{abstract}
${ }^{1}$ Laboratory of Clinic, Faculty of Veterinary Medicine, Universitas Syiah Kuala, Banda Aceh 23111, Aceh, Indonesia
${ }^{2}$ Graduate School of Mathematics and Applied Science, Universitas Syiah Kuala, Banda Aceh 23111, Indonesia

${ }^{3}$ Laboratory of Anatomy, Faculty of Veterinary Medicine, Universitas Syiah Kuala, Banda Aceh 23111, Aceh, Indonesia

${ }^{4}$ Laboratory of Physiology, Faculty of Veterinary Medicine, Universitas Syiah Kuala, Banda Aceh 23111, Aceh, Indonesia

${ }^{5}$ Laboratory of Reproduction, Faculty of Veterinary Medicine, Universitas Syiah Kuala, Banda Aceh 23111, Aceh, Indonesia
\end{abstract}

Syafruddin S., Wahyuni S., Gholib G., Siregar T. N.

Comparison of four methods of inducing pseudopregnancy in rabbits

Summary

This study was conducted to compare several methods for inducing pseudopregnancy in local rabbits. The study used 25 clinically healthy rabbits of local breeds, aged 1-1.5 years, with a bodyweight of 1.8-2.2 $\mathrm{kg}$. The rabbits were divided into five treatment groups $(n=5): R 1, R 2, R 3, R 4$, and $R 5$. Each group was given a different treatment. Group R1 was injected intramuscularly with 100 IU PMSG and mated with males three days later, which was followed by an intravenous injection of 75 IU hCG. Pseudopregnancy in group R2 was induced through artificial copulation by inserting a $1 \mathrm{~cm}$ long cotton bud into vaginal lumen at 5 a.m. Pseudopregnancy in group R3 was induced using 50 IU hCG intramuscularly. Group R4 was injected intravenously with $5 \mathbf{g}$ GnRH and then intramuscularly with 100 IU PMSG and three days later with 75 IU hCG. Blood samples were collected on days $2,4,6$, and 8 for estrogen and progesterone measurement, whereas an ovarian histological observation of all groups was performed on day 8 . The results show that the highest concentration of estrogen was obtained in group $R 2$, which was significantly different from the other groups $(P<0.05)$, but the difference in examination time was not statistically significant $(P>0.05)$. Furthermore, the concentration of progesterone in all groups fluctuated at various times of the day. Progesterone concentrations were higher in group R5, in which pseudopregnancy was induced with PMSG and hCG. Group R5 showed a significant difference $(P<0.05)$ with $R 2$, R3, and R4, but the difference with the positive control group (R1) was not significant $(P>0.05)$. The numbers of corpora lutea in groups $R 1, R 2, R 3, R 4$, and $R 5$ were, respectively, $6.87 \pm 1.58,6.22 \pm 2.71,6.74 \pm 1.94$, $5.98 \pm 2.04$, and $8.8 \pm 1.90$, and the largest diameter was obtained in $R 5(1.65 \pm 0.37 \mathrm{~mm})$. In conclusion, the best method of inducing pseudopregnancy in local rabbits is the administration of PMSG and hCG.

Keywords: local rabbits, ovarian response, pseudopregnancy, steroid

Pseudopregnancy is a phenomenon in rabbits and other animals in the progestational state in which endometrial and endocrinological changes occur from early pregnancy and lactation in the absence of fertilization (4). Pseudopregnancy in rabbits can occur due to several factors, including sterile mating, LH injection, or stimulation when the female rabbit mounts another rabbit. In a normal estrous cycle, the corpus luteum regresses if the female rabbit fails to conceive. However, in pseudopregnant female rabbits, the corpus luteum remains and continues to release progesterone, the hormone responsible for maintaining pregnancy. Pseudopregnancy in rabbits generally lasts 16-18 days, and continued secretion of progesterone causes physical and behavioral changes consistent with normal pregnancy (8).

The pseudopregnant rabbit is an animal model commonly used for studies of reproductive endocrinology (13), for treatment of endometriosis (30), and for ovarian transplantation as a source of oocytes (26). This can be done because, at the beginning of pregnancy, the glands found in the rabbit's endometrium will actively produce secretions in the uterine lumen as nutritional reserves for the embryo prior to implantation (11).

Several methods of inducing pseudopregnancy have been developed, such as ovulation induction by injection of hCG (1), GnRH (29), or PMSG and hCG (22), and the physical stimulation method (26). The physical 
stimulation method or artificial copulation is a simple and economical method of inducing pseudopregnancy (10). Kaneko et al. (15) succeeded in inducing pseudopregnancy in female rats by artificial stimulation through sonic vibrations. These methods need to be tested to find the best method for the induction of pseudopregnancy in rabbits.

There are many methods to test the success of pseudopregnancy induction. Methods with good validity are the measurement of the hormone estradiol and progesterone, and observation of ovarian response, which includes the development of follicles and the corpus luteum. Caillol et al. (7) reported that the concentration of progesterone in pseudopregnant rabbits increased on days 4 and 5 and reached a peak on day 11 , after which the concentration decreased slowly and reached basal levels on days 19 to 20. Meanwhile, the concentration of oestrogen fluctuated between 0 and $140 \mathrm{pg} / \mathrm{mL}$, with oestradiol levels slightly higher than those of estrone. However, there was no definite change in estrogen levels during pseudopregnancy.

\section{Material and methods}

This study used 25 clinically healthy rabbits of local breeds, aged 1-1.5 years, with a body weight of $1.8-2.2 \mathrm{~kg}$. Prior to induction of pseudopregnancy, each rabbit was placed in an individual cage for three weeks. The rabbits were divided into five treatment groups: R1, R2, R3, R4, and R5. Each group was given a different treatment. Group R1 was injected intramuscularly with 100 IU PMSG (Folligon, BV Boxmer, Netherlands) and mated with males three days later, which was followed by an intravenous injection of $75 \mathrm{IU}$ hCG (Chorulon, BV Boxmer, Netherlands). Pseudopregnancy in group R2 was induced through artificial copulation by inserting a $1 \mathrm{~cm}$ long cotton bud into vaginal lumen at 5 a.m. (26). Group R3 was given an intramuscular injection of 50 IU hCG (Chorulon, BV Boxmer, Netherlands) (1). Group R4 was injected intravenously with $5 \mathrm{~g}$ GnRH (Fertagyl, BV Boxmer, Netherlands) (29) and then intramuscularly with 100 IU PMSG (Folligon, BV Boxmer, Netherlands) and three days later with 75 IU hCG (Chorulon, BV Boxmer, Netherlands) (22).

Collection of blood samples and hormone analysis. The blood of all groups was collected from the auricular vein with a $1 \mathrm{ml}$ syringe on days $2,4,6$, and 8 . Day 0 of treatment was the day of mating for R1, the day of copulation for R2, the day of injection of hCG or GnRH for R3 and R4, and the day of injection of hCG for R5. The blood samples obtained were put into blood tubes and stored in a cool box until processing in the laboratory. Furthermore, the blood samples were centrifuged at $2500 \mathrm{rpm}$ for $15 \mathrm{~min}$ utes, and the serum samples obtained were transferred into microtubes and stored in a freezer at $-20^{\circ} \mathrm{C}$ until hormone measurement. In this study, we used an enzyme-linked immunosorbent assay (ELISA) technique for measuring the concentration of estradiol and progesterone. The hormone analysis was performed according to the instructions from the manufacturer of the ELISA for estradiol and progesterone (DRG, GmbH Instruments, Germany).
Histological preparation. Histological preparation was carried out according to Kiernan (17). The ovaries of all groups were collected on the eighth day of treatment and fixed using the immersion fixation technique in a $10 \%$ neutral buffer formalin (NBF) solution and then transferred to $70 \%$ ethanol. Ovarian tissue was cut longitudinally, placed in a tissue cassette, dehydrated in graded ethanol $(70 \%, 80 \%, 90 \%$, and absolute), cleared in xylene solution, immersed in paraffin infiltration, and finally embedded in a paraffin block. The tissue in paraffin blocks was cut into $5 \mu \mathrm{m}$ thick slices with a rotary microtome (Leica RM2235) and placed on glass slides. Prior to staining with hematoxylin-eosin (HE), the paraffin was removed by immersing the slides in xylene solution. They were rehydrated with ethanol, stained with HE, dehydrated, cleared, and mounted with cover slides using Entellan (Merck, Germany).

Microscopic examination. To determine the number of follicle and stage of follicular development, as well as the number and diameter of corpora lutea, all histological slides were observed under a light microscope and analyzed with the ToupView software (Sigma). Primary follicles are characterized by the change in shape of flattened pre-granulosa cells into cuboidal granulosa cells. Secondary follicles are characterized by the formation of two or more layers of granulosa cells and the formation of zona pellucida that surrounds the oocyte. Furthermore, tertiary follicles (antral follicles) are characterized by the formation of more than five layers of granulosa cells and expansion of follicular antrum. Theca externa cells arrange themselves around the follicle, and cells surrounding the zona pellucida begin to form the corona radiata (12). The corpus luteum is characterized by extensive structural and cellular changes in the preovulatory follicle, leading to ovulation and formation of the corpus luteum. The new corpus luteum develops from cells that remain in the follicular wall after ovulation, but eventually consists of several distinctive cell types, including steroidogenic luteal cells (small and large cells derived from theca and granulosa cells, respectively) and non-steroidogenic cells (16).

Data analysis. The data on estrogen and progesterone concentration were analyzed by two-way analysis of variance (ANOVA), while the number of tertiary follicles and the diameter of the corpus luteum were analyzed by oneway ANOVA.

\section{Results and discussion}

Some authors have reported on the concentration of estrogen in pseudopregnant rabbits. The concentration of estrogen fluctuated between 32 and $49 \mathrm{pg} / \mathrm{mL}$ and slowly increased until the end of the pseudopregnancy period (16). According to another source, estrogen concentration in pseudopregnant rabbits fluctuated from 0 to $140 \mathrm{pg} / \mathrm{mL}$ (7). In the present study, the concentration of estrogen fluctuated in all groups, and the highest total concentration was observed in group R2 (artificial copulation).

Estrogen concentrations in all groups on days 2, 4, 6 , and 8 of treatment are presented in Table 1. Estrogen concentrations at different examination times showed 
Tab. 1. Mean $( \pm$ SD) of estrogen and progesterone $(\mathrm{ng} / \mathrm{mL})$ concentrations in five rabbit groups on days $2,4,6$, and 8 of treatment

\begin{tabular}{|c|c|c|c|c|c|c|}
\hline \multirow{2}{*}{ Hormones } & \multicolumn{5}{|c|}{ Induction treatment groups } & \multirow{2}{*}{ Total } \\
\hline & R1 & R2 & R3 & R4 & R5 & \\
\hline \multicolumn{7}{|l|}{ Estrogen } \\
\hline Day-2 & $76.35 \pm 6.03$ & $142.47 \pm 6.38$ & $58.65 \pm 21.78$ & $58.82 \pm 27.54$ & $72.30 \pm 30.60$ & $81.71 \pm 34.87$ \\
\hline Day-4 & $30.75 \pm 10.92$ & $143.75 \pm 27.10$ & $62.21 \pm 27.92$ & $60.25 \pm 23.07$ & $82.90 \pm 19.44$ & $75.97 \pm 42.20$ \\
\hline Day-6 & $63.14 \pm 20.05$ & $136.87 \pm 18.70$ & $74.53 \pm 15.81$ & $69.22 \pm 18.96$ & $101.64 \pm 26.2$ & $89.08 \pm 30.49$ \\
\hline Day-8 & $74.60 \pm 14.03$ & $139.59 \pm 15.47$ & $72.88 \pm 23.87$ & $57.53 \pm 22.44$ & $86.69 \pm 19.20$ & $86.25 \pm 31.56$ \\
\hline Total & $61.73 \pm 20.7^{A}$ & $134.02 \pm 22.3^{B}$ & $65.13 \pm 20.3^{A}$ & $56.06 \pm 23.0^{A}$ & $79.67 \pm 26.1^{A}$ & \\
\hline \multicolumn{7}{|l|}{ Progesterone } \\
\hline Day-2 & $10.08 \pm 2.07$ & $0.48 \pm 0.42$ & $2.07 \pm 21.04$ & $1.47 \pm 0.80$ & $3.63 \pm 1.01$ & $3.54 \pm 3.82^{\mathrm{a}}$ \\
\hline Day-4 & $2.10 \pm 1.41$ & $2.02 \pm 0.97$ & $9.35 \pm 1.12$ & $4.30 \pm 1.81$ & $9.21 \pm 1.79$ & $5.39 \pm 3.66^{b}$ \\
\hline Day-6 & $4.15 \pm 1.98$ & $0.71 \pm 0.21$ & $7.75 \pm 0.69$ & $6.11 \pm 1.49$ & $13.27 \pm 1.18$ & $6.39 \pm 4.65^{c}$ \\
\hline Day-8 & $6.40 \pm 1.09$ & $1.09 \pm 0.21$ & $8.01 \pm 1.04$ & $1.48 \pm 1.23^{B}$ & $12.33 \pm 1.05$ & $5.86 \pm 4.70^{b}$ \\
\hline Total & $7.07 \pm 4.18^{D}$ & $0.99 \pm 0.73^{A}$ & $5.71 \pm 3.49 \mathrm{c}$ & $2.88 \pm 2.35^{B}$ & $7.92 \pm 5.00^{\circ}$ & \\
\hline
\end{tabular}

Explanations: A, B, C, D, E - Different superscripts in the same line indicate significant differences $(\mathrm{P}<0,05)$; $\mathrm{a}, \mathrm{b}, \mathrm{c}-\mathrm{Different}$ superscripts in the same column indicate significant differences $(\mathrm{P}<0,05)$; R1 - PMSG, hCG, and mating; R2 - artificial copulation; R3 - hCG; R4 - GnRH; R5 - PMSG, hCG

Tab. 2. Ovarian response induced by various pseudopregnancy treatments in rabbits according to the number and diameter of follicles and corpora lutea

\begin{tabular}{|c|c|c|c|c|c|}
\hline \multirow{2}{*}{ Ovarian response on day 8} & \multicolumn{5}{|c|}{ Induction treatment groups } \\
\hline & R1 & $\mathbf{R} 2$ & R3 & R4 & R5 \\
\hline Number of follicles with diameter $>0.4 \mathrm{~mm}$ & $2.12 \pm 1.23^{\mathrm{a}}$ & $1.10 \pm 0.00^{\mathrm{a}}$ & $3.09 \pm 2.10^{b}$ & $3.31 \pm 1.42^{b}$ & $6.27 \pm 2.94^{c}$ \\
\hline Proportion of rabbits that ovulated & $4 / 5$ & $5 / 5$ & $5 / 5$ & $5 / 5$ & $5 / 5$ \\
\hline Number of corpora lutea on day 8 & $6.87 \pm 1.58^{b}$ & $6.22 \pm 2.71^{\mathrm{a}}$ & $6.74 \pm 1.94^{b}$ & $5.98 \pm 2.04^{\mathrm{a}}$ & $8.80 \pm 1.90^{c}$ \\
\hline Diameter of corpus luteum on day 8 (mm) & $1.39 \pm 1.17^{b}$ & $0.85 \pm 0.27^{\mathrm{a}}$ & $0.91 \pm 0.27^{\mathrm{a}}$ & $1.02 \pm 0.13^{\mathrm{a}}$ & $1.65 \pm 0.37^{b}$ \\
\hline
\end{tabular}

Explanations: a, b, c - Different superscripts in the same line indicate significant differences $(\mathrm{P}<0,05)$; R1 - PMSG, hCG, and mating; R2 - artificial copulation; R3 - hCG; R4 - GnRH; R5 - PMSG, hCG

no significant differences $(\mathrm{P}>0.05)$. This is in accordance with a previous study, in which the concentration of estrogen in pregnant and pseudopregnant rabbits was the same during the first 6 days, which indicated the same pattern of follicular growth after ovulation in both groups, so it was suspected that all treatments succeeded in inducing pseudopregnancy (6). Although both pregnancy and pseudopregnancy are associated with increased progesterone concentration and formation of corpora lutea (Tab. 1 and Tab. 2), the patterns of these changes are different. Pseudopregnancy was successfully induced in groups R3 (hCG) and R5 (PMSG and hCG). Therefore, judging by the results of this study, measuring estrogen as an indicator of the success of pseudopregnancy induction is not recommended.

The high concentration of estrogen in R2 compared to other groups $(\mathrm{P}<0.05)$ indicated that follicle growth in R2 occurred without ovulation. Ovulation that occurred in the other groups caused an increase in the concentration of progesterone. An increase in the concentration of progesterone reduced the secretion of estrogen. The administration of progesterone to rabbits stimulated by estrogen suppressed their sexual accep- tance, which was thought to mean that progesterone would suppress the function of estrogen (5).

Progesterone concentrations in all rabbit groups on days 2, 4, 6, and 8 of treatment are presented in Table 1 . It can be seen that all groups showed fluctuations at different times of the day. Progesterone concentrations were found to be higher in group R5, in which pseudopregnancy was induced with PMSG and hCG. R5 showed no significant difference $(\mathrm{P}>0.05)$ with the positive control group (R1).

Judging by the progesterone concentration, pseudopregnancy was successfully induced in groups R3 (hCG) and R5 (PMSG and hCG), as the progesterone levels in these groups were close to or exceeded those in pregnant rabbits (R1). Although the pregnancy diagnosis in R1 was not tested, given the progesterone concentration obtained and the fact of mating, it was suspected that the rabbits were pregnant. The concentration of progesterone in pregnant rabbits was $9.4 \mathrm{ng} /$ $\mathrm{mL}$ (27). However, Kleden et al. (18) reported a lower concentration of $3.1 \mathrm{ng} / \mathrm{mL}$ in pregnant rabbits. Judging by the progesterone concentration, pseudopregnancy induction with hCG or PMSG and hCG was successful because the progesterone concentration obtained was 
close to or greater than it was in the group of rabbits that were considered pregnant. Different results were reported by Browning et al. (6), who showed that the concentration of progesterone in pseudopregnant local rabbits was lower than in pregnant rabbits, whereas Holt et al. (14) observed that the concentration of progesterone in pregnant and pseudopregnant rabbits did not fluctuate during the implantation period.

The results of this study suggest that, judging by the concentration of progesterone, artificial copulation (R2) and injection of GnRH (R4) are not effective methods for inducing pseudopregnancy in local rabbits. The mean concentrations of progesterone until day 8 or during the implantation period were $0.99 \pm 0.73$ in R2 and $2.88 \pm 2.35 \mathrm{ng} / \mathrm{mL}$ in R4. Progesterone concentrations in pseudopregnant rabbits increase from day 4-5 after induction and decrease to basal levels on days 19-20 (7). The progesterone concentration on day 8 in pseudopregnancy induced by GnRH should be greater than $5 \mathrm{ng} / \mathrm{mL}(10)$. Although the progesterone concentration induced by GnRH in this study was lower, it was still in line with that reported by Browning et al. (6).

In the present study, progesterone concentrations on day 6 in pseudopregnant rabbits from groups R3 and R5 were already greater than $5 \mathrm{ng} / \mathrm{ml}$. On the other hand, Cervantes et al. (10) reported that, in pseudopregnancy induced with $\mathrm{GnRH}$, concentrations greater than $5 \mathrm{ng} / \mathrm{mL}$ were achieved on day 8 . In general, according to progesterone measurement, the concentration of progesterone in pseudopregnant rabbits from groups R3 and R5 were high and reflected the occurrence of ovulation, as reported by Kleden et al. (18) and Cervantes et al. (10). In group R5, the progesterone concentration increased on successive days, while in R1 it tended to fluctuate even though it was greater than 5 $\mathrm{ng} / \mathrm{mL}$ from the fourth day onwards. Caillol et al. (7) observed that the concentration of progesterone began to increase from the fourth to fifth day of pseudopregnancy and was at its highest on day 11.

Considering that the rabbits in group $\mathrm{R} 1$ were mated, their progesterone levels should have been higher than those of rabbits in $\mathrm{R} 5$. Mating in rabbits stimulates $\mathrm{LH}$ secretion from the anterior pituitary, which is responsible for follicular development and ovulation. This condition was probably due to differences in the rabbits' response to PMSG. This can be proven by higher estradiol concentrations in R5 compared to R1. It is confirmed by the fact that the number and diameter of corpora lutea in R5 were relatively greater even though the difference was not statistically significant $(\mathrm{P}>0.05)$, as shown in Table 2. The numbers of corpora lutea were $6.87 \pm 1.58$ in $\mathrm{R} 1$ and $8.8 \pm 1.9$ in R5, whereas the diameters were $1.39 \pm 1.17 \mathrm{~mm}$ in $\mathrm{R} 1$ and $1.65 \pm 0.37 \mathrm{~mm}$ in R5. The difference in the number of rabbits that ovulated might have affected the number of corpora lutea formed because in R1 there was one rabbit that failed to ovulate, and the cause could not be explained from the results of this study.

In this study, primary, secondary, and tertiary follicles were identified in each group, as shown in Figure 1. Primordial follicle formation occurs 17-54 days after birth, with each follicle containing a small oocyte with a single layer of flat granulosa cells, but no zona pellucida. On day 120 , each primary follicle contains a small pale oocyte with a specific zona pellucida and a single layer of cuboidal granulosa cells (23).

The next phase of development of the primary follicle is the formation of a secondary follicle. In this phase, for the first time, the follicle undergoes cell multiplication, and there is a second layer around the oocyte. During the subsequent development, secondary follicles are surrounded by irregular spaces, which are the result of differentiation of stromal cells from the ovary. These epithelial cells then form the theca follicular. At the end of the secondary follicle development, the theca follicular separates into the theca interna and theca externa (20).
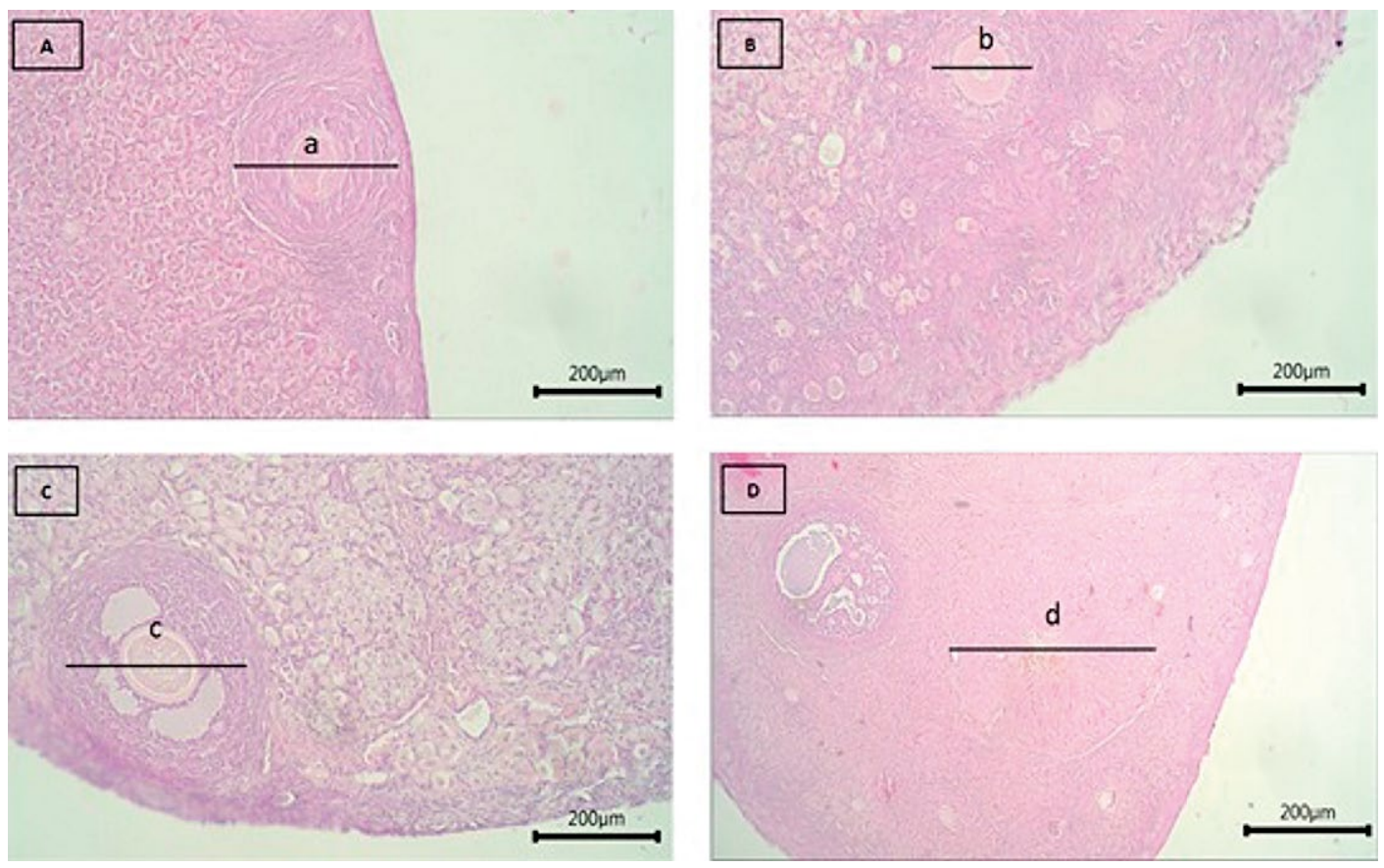

Fig. 1. Different stages of ovarian follicle development in a local rabbit. A. primary follicle, B. secondary follicles, C. tertiary follicle, and D. corpus luteum. Diameter of primary follicle (a), secondary follicle (b), tertiary follicle (c), and corpus luteum (d). H\&E staining 
After the separation between the theca interna and theca externa, follicular cavities (antrum) appear within the layer of granulosa cells. The cavity is formed due to the rapid growth of granulosa cells that are on the outside and the slow growth of granulosa cells that are in the inner layer. The increase of the diameter of antrum follicular is accordance with follicular growth, that marked by the disappear of the barrier between the antrum until only one very large antrum remains. Such follicles are known as tertiary follicles (20).

The corpus luteum is characterized by extensive structural, cellular, and molecular changes in the preovulatory follicle, leading to ovulation and formation of the corpus luteum. The new corpus luteum develops from cells that remain in the follicular wall after ovulation, but eventually consists of several typical cell types, including steroidogenic luteal cells (small and large cells derived from theca and granulosa cells, respectively) and non-steroidogenic cells (16).

Although all follicle stages were counted, only follicles greater than $0.4 \mathrm{~mm}$ in size were included for statistical data analysis. This decision was based on measurements of tertiary follicles, all of which are greater than $0.4 \mathrm{~mm}$ in size. Cervantes et al. (10) also reported the effect of ovulation induction treatment on rabbits with follicles over $1.5 \mathrm{~mm}$ in size. In another study, the follicle size in estrus rabbits ranged from 0.95 to $1.42 \mathrm{~mm}(21)$. The diameters of the follicles in this study were relatively small, which was probably due to differences in rabbit breeds and measurement time. Rone et al. (21) conducted a study on New Zealand White rabbits in estrus and measured their follicles on day 8 after ovulation induction.

In the present study, the numbers of follicles larger than $0.4 \mathrm{~mm}$ on the eighth day of treatment were significantly different $(\mathrm{P}<0.05)$, with the highest number in group R5. The numbers of follicles in groups R1, $\mathrm{R} 2, \mathrm{R} 3, \mathrm{R} 4$, and R5 were, respectively, $5.9 \pm 1.45$, $0.63 \pm 0.35,3.09 \pm 2.10,3.31 \pm 1.42$, and $2.06 \pm 1.50$, as shown in Table 2. In contrast, Cervantes et al. (10) found that there was no difference in the number of follicles measuring more than $1.5 \mathrm{~mm}$ between different ovulation induction treatments. The decrease in the number of tertiary follicles in R1 and R2 in this study is thought to have been due to the limited response to treatment and some follicles that were ovulated. This is supported by the number of corpora lutea, which indicates ovulation. This supposition is also supported by Kranzfelder et al. (19), who claim that rabbits lose large follicles after ovulation.

With a total of $6.27 \pm 2.94$, the number of tertiary follicles in R5 was higher than it was in the other groups, although not significantly so $(\mathrm{P}>0.05)$. This result is in agreement with a report by Siregar et al. (25) that a higher number of tertiary follicles in mice can be induced with PMSG and hCG. It is thought that hCG can speed up the transformation of secondary follicles into tertiary follicles because secondary follicles already have receptors for $\mathrm{LH}$ (31). This opinion is inconsistent with the fact that group $\mathrm{R} 1$, in which pseudopregnancy was induced with PMSG, hCG, and mating, produced fewer tertiary follicles than did R5, which was injected with PMSG and hCG, but did not mate. Theoretically, copulation should stimulate an increase in LH secretion from the anterior pituitary. This secretion, together with the induction by hCG injection is expected to increase folliculogenesis and result in the formation of more tertiary follicles. It is suspected that the LH concentration due to copulation is sufficient to stimulate folliculogenesis in rabbits, so that exogenous administration of hCG is no longer needed. However, there is still a need for an in-depth study on this matter. In addition, it is possible that individual response affected the number of tertiary follicles in R1 because there was one rabbit that did not show signs of ovulation, which indicates a disturbance of folliculogenesis and ovulation.

All rabbits that ovulated in the induction groups showed ovulation, which was indicated by the formation of a corpus luteum. Because of the difficulty of determining the presence and size of a corpus luteum by visual observation, in this study observation was carried out microscopically. The numbers of corpora lutea in groups R1, R2, R3, R4, and R5 were, respectively, $6.87 \pm 1.58,6.22 \pm 2.71,6.74 \pm 1.94,5.98 \pm 2.04$, and $8.8 \pm 1.90$, and the largest diameter was obtained in R5 $(1.65 \pm 0.37 \mathrm{~mm})$, as shown in Table 2 .

The occurrence of ovulation in R2 after artificial copulation is in line with results obtained by Sumarmin et al. (10), who induced pseudopregnancy in New Zealand White rabbits by artificial copulation according to the same procedure as the one used in the present study. Artificial copulation is thought to have the same effect as mating, which causes sequential events in the hypothalamus, followed by a surge in LH. The LH surge then triggers ovulation, which occurs around 11-12 hours after mating $(2,9)$. As far as group R3 is concerned, the success of inducing pseudopregnancy with hCG has been reported by Abd-Elkareem et al. (1), hCG caused an increase in progesterone receptor in the rabbit uterus. In R4, GnRH induced ovulation, which is in line with a report by Singh and Khrisna (24) showing that GnRH secreted in the hypothalamus stimulates the release of FSH and $\mathrm{LH}$, which regulate folliculogenesis and ovulation.

The number of ovulations and the diameter of the corpus luteum in different groups showed significant differences $(P<0.05)$, and the highest number of corpora lutea were obtained in R5. This difference in corpora lutea corresponded to the higher progesterone concentration in R5 compared to the other groups. According to Tjitosumirat (28), the concentration of progesterone can be used to predict the number of ovulations in small ruminants. 


\section{References}

1. Abd-Elkareem M. D.: Morphological, histological and immunohistochemical study of the rabbit uterus during pseudopregnancy. J. Cytol. Histol. 2017, 1, 1-7.

2. Bakker J., Baum M. J.: Neuroendocrine regulation of GnRH release ininduced ovulators. Frontiers in Neuroendocrinol. 2000, 21, 220-262.

3. Batra S., Owman Ch., Sjoeberg N. O., Thorbert G.: Relationship between plasma and uterine estradiol in pseudopregnant rabbits. J. Reprod. Fert. 1979, $56,1-5$.

4. Bellofiore N., Ellery S. J., Smith P. T., Evans J.: Pseudopregnancy and reproductive cycle synchronization cannot be induced using conventional methods in the spiny mouse (Acomys cahirinus). Reprod. Fertil. Develop. 2019, 32, $1-10$.

5.Boiti C., Besenfelder U., Brechhia G., Theaw-Clement M., Zerani M.: Reproductive physiopathology of the rabbit doe, [in:] Maerkens L., Coudert P. (eds): Recent Advances in Rabbit Sciences. Institute for Agricultural and Fisheries Research (ILVO), Belgium 2006.

6. Browning J. Y., Keyes P. L., Woli R. C.: Comparison serum progesteron, $20 \alpha$-dihydroprogesterone, and estradiol-17 $\beta$ in pregnant and pseudopregnant rabbits, evidence for postimplantation recognition of pregnancy. Biol. Reprod. 1980, 23, 1014-1019.

7. Caillol M., Villemant C. D., Martinet L.: Oestrus behaviour and circulating progesterone and oestrogen levels during pseudopregnacy in the domestic rabbit. J. Reprod. Fert. 1983, 1, 180-186.

8. Carter C. L., Adams J. K., Czarra J. A., Coan P. N.: An incidence of pseudopregnancy associated with the social enrichment of rabbits (Oryctolagus cuniculi). J. Am. Assoc. Lab. Anim. Sci. 2016, 1, 98-99.

9. Centeno M. L., Luo J., Lindstrom J. M., Caba M., Pau K. Y. F.: Expression of alpha 4 and alpha 7 nicotinic receptors in the brainstem of female rabbits after coitus. Brain Res. 2004, 1012, 1-12.

10. Cervantes M. P., Palomino J. M., Adams G. P.: In vivo imaging in the rabbit as a model for the study of ovulation-inducing factors. Lab. Anim. 2015, 49, 1-9.

11. Colby E. D.: The rabbit, [in:] D. A. Morrow (ed.): Current Theraphy in Theriogenology 2. Saunders W. B. Co, Philadelphia 1986

12. Cushman R. A., Wahl C. M., Fortune J. E.: Bovine ovarian cortical pieces grafted to chick embryonic membranes: A model for studies on the activation of primordial follicles. Hum. Reprod. 2002, 1, 48-54.

13. Dugre F. J., Lambert R. D., Belanger A., Fortier M. A., Caron S.: Local effect of the rabbit embryo-foetus on uterine progesterone and pregnenolone levels. Mol. Cell Endocrinol. 1989, 2, 251-255.

14. Holt J. A., Heise W. F., Wilson S. M., Keyes P. L.: Lack of gonadotropin activity in the rabbit blastocyst prior to implantation. Endocrinology 1976, 98, 904-909.

15. Kaneko T., Endo M., Tsunoda S., Nakagawa Y., Abe H.: Simple induction of pseudopregnancy by artificial stimulation using a sonic vibration in rats. Sci. Reports 2020, 10, 1-5.
16. Kfir S., Basavaraja R., Wigoda N., Ben-Dor S., Orr I., Meidan R.: Genomic profiling of bovine corpus luteum maturation. Public Lib. Sci. 2018, 3, 1-19.

17. Kiernan J. A.: Histological and Histochemical Methods: Theory and Practice. Pergamond, England 1990.

18. Kleden M. M., Soetanto H., Kusmartono A., Kuswanto A.: Concentration of progesterone and prolactin hormones and milk production of New Zealand White rabbits doe fed moringa leaves meal. Mediterranean J. Soc. Sci. 2017, 8, 79-85.

19. Kranzfelder D., Korr H., Mestwerdt W., Schultze B. M.: Follicle growth in the ovary of the rabbit after ovulation-inducing application of human chorionic gonadotropin. Cell Tissue Res. 1984, 238, 611-620.

20. Partodihardjo S.: Ilmu Reproduksi Hewan. Mutiara Press, Jakarta 1980

21. Rone J. D., Halvorson L. M., Goodman A. L.: Ovarian angiogenesis in rabbits: Endotheliotrophic chemoattractant activity from isolated follicles and dispersed granulose cells. J. Reprod. Fertil. 1993, 97, 359-365.

22. Schlegel W., Kruger S., Daniels D., Fischer B., Schneider H. P. G., Beier H. M.: Studies on prostaglandin metabolism in corpora lutea of rabbits during pregnancy and pseudopregnancy. J. Reprod. Fertil. 1988, 1, 365-370.

23. Songsasen N., Fickes A., Pukazhenthi B. S., Wildt D. E.: Follicular morphology, oocyte diameter and localization of fibroblast growth factors in the domestic dog ovary. Reprod. Dom. Anim. 2009, 2, 65-70.

24. Singh P., Krishna A.: Effects of GnRH agonist treatment on steroidogenesis and folliculogenesis in the ovary of cyclic mice. J. Ovarian Res. 2010, 3, 1-13.

25. Siregar I. K., Siregar T. N., Akmal M., Wahyuni S., Nazaruddin, Hafizuddin. Efek pemberian ekstrak pituitary sapi terhadap peningkatan jumlah folike ovarium dan konsentrasi estradiol pada tikus putih (Rattus norvegicus). Livest. Anim. Res. 2020, 18, 171-189.

26. Sumarmin R., Winarto A., Yusuf T. L., Boediono A.: Perkembangan folikel dan viabilitas oosit domba pascatransplantasi ovarium domba intrauterin pada kelinci bunting semu. J. Vet. 2008, 3, 115-121.

27. Szendrö Zs., Matics Zs., Brecchia G., Theau-Clément M., Nagy Z., Princz Z., Biró-Németh E., Radnai I., Nagy I.: Milk production of pseudopregnant and multiparous does. World Rabbit Sci. 2010, 18, 77-82.

28. Tjitosumirat T: : Studi hubungan konsentrasi hormon progesterone dengan jumlah corpus luteum pada kambing. Sci. J. Appl. Isotopes Radiation 2009, $5,43-53$

29. Viudes-de-Castro M. P., Lavara R., Marco-Jimenez F., Cortell C., Vicente J. S. Ovulation induced by mucosa vaginal absorption of buserelin and triptorelin in rabbit. Theriogenology 2007, 7, 1031-1036.

30. Yuan P., Huang Y., Wu H., Teng Z., Zhang J., Xin X.: Induction of a local pseudopregnancy via levonorgestrel-loaded microspheres for the treatment of endometriosis in a rabbit model. Hum. Reprod. 2010, 2, 462-469.

31. Zoheir K. M. A., Harisa G. I., Allam A. A., Yang L., Li X., Liang A., Abd-Rabou A. A., Harrath A. H.: Effect of alpha lipoic acid on in vitro development of bovine secondary preantral follicles. Theriogenology 2017, 15, 124-130.

Corresponding author: Prof. Dr. drh. Tongku Nizwan Siregar, M.P., Laboratory of Reproduction, Faculty of Veterinary Medicine, Universitas Syiah Kuala, Banda Aceh 23111, Aceh, Indonesia; e-mail: siregar@unsyiah.ac.id 